\title{
Parallel DNA polymerase chain reaction: Synthesis of two different PCR products from a DNA template [version 1; peer
}

\section{review: 2 approved]}

\author{
Vikash Bhardwaj", Kulbhushan Sharma² \\ ${ }^{1}$ Molecular Biology and Genetics Domain, Lovely Professional University, Punjab, 144411, India \\ ${ }^{2}$ MCS Group, Institute of Nuclear Medicine and Allied Sciences (INMAS), Timarpur, Delhi, 110054, India
}

V1 First published: $31 \mathrm{Dec} 2014, \mathbf{3 : 3 2 0}$

https://doi.org/10.12688/f1000research.5813.1

Latest published: 31 Dec 2014, 3:320

https://doi.org/10.12688/f1000research.5813.1

\section{Abstract}

Conventionally, in a polymerase chain reaction (PCR), oligonucleotide primers bind to the template DNA in an antiparallel complementary way and the template DNA is amplified as it is. Here we describe an approach in which the first primer binds in a parallel complementary orientation to the single-stranded DNA, leading to synthesis in a parallel direction. Further reactions happened in a conventional way leading to the synthesis of PCR product having polarity opposite to the template used. This is the first study showing that synthesis of DNA can happen also in a parallel direction. We report that from a singlestranded DNA template, two different but related PCR products can be synthesized.

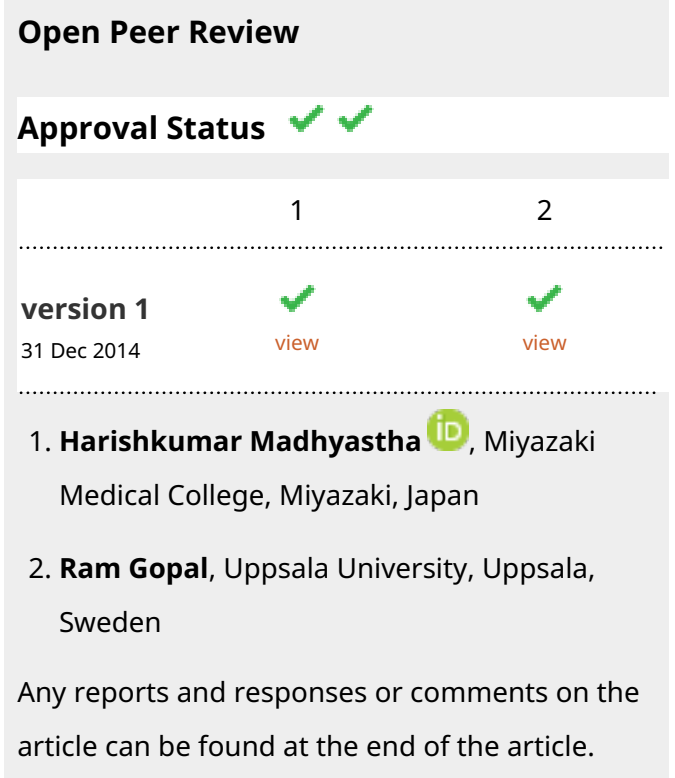

Corresponding author: Vikash Bhardwaj (vikashbhardwaj@gmail.com)

Competing interests: No competing interests were disclosed.

Grant information: The author(s) declared that no grants were involved in supporting this work.

Copyright: ( 2014 Bhardwaj V and Sharma K. This is an open access article distributed under the terms of the Creative Commons Attribution License, which permits unrestricted use, distribution, and reproduction in any medium, provided the original work is properly cited. Data associated with the article are available under the terms of the Creative Commons Zero "No rights reserved" data waiver (CC0 1.0 Public domain dedication).

How to cite this article: Bhardwaj V and Sharma K. Parallel DNA polymerase chain reaction: Synthesis of two different PCR products from a DNA template [version 1; peer review: 2 approved] F1000Research 2014, 3:320

https://doi.org/10.12688/f1000research.5813.1

First published: 31 Dec 2014, 3:320 https://doi.org/10.12688/f1000research.5813.1 


\section{Introduction}

Our fundamental knowledge of DNA structure is based on the Watson-Crick model of DNA double helix, in which two polynucleotide chains running in opposite direction are held together by hydrogen bonds between the nitrogenous bases. Guanine can bind specifically only to cytosine (G-C) whereas adenine can bind specifically to thymine (A-T). These reactions are described as base pairing and the paired bases are said to be "complementary". Conformational polymorphism of DNA is now extending beyond the Watson-Crick double helix. In 1986, using forced field calculation for a short 'A-T' rich DNA, Pattabiraman proposed the hypothesis that homopolymeric duplex DNA containing d(A)6d.(T)6 can form a thermodynamically stable parallel right-handed duplex DNA with reverse Watson-Crick base pairing. He also reported that the number and type of hydrogen bonds between A-T base pair are the same as that of antiparallel double helix ${ }^{2}$. In 1988, the experimental strategies by Ramsing and Jovin confirmed that DNA containing A-T base pairs can exist as a stable parallel-stranded helix. The "Tm" value of both PS-DNA (parallel-stranded DNA) and APS-DNA (antiparallel-stranded DNA) showed a classical dependence upon salt concentration. They reported that at any given $\mathrm{NaCl}$ concentration, the melting temperature of PS-DNA was $15^{\circ} \mathrm{C}$ lower than its APS-DNA counterpart. In $2 \mathrm{mM} \mathrm{MgCl}_{2}$, the melting temperature for PS-DNA and APS-DNA was reported approximately same as those obtained in $0.2-0.3 \mathrm{M} \mathrm{NaCl}$, demonstrating pronounced stabilization afforded by divalent cations ${ }^{3}$. A similar study by Sande et al. on hairpin deoxyoligonucleotides having oligonucleotides sequence in parallel polarities (PS-hairpin) also confirmed the existence of parallel-stranded conformation. They have shown that parallel-stranded hairpins form stable duplex and get denatured at $10^{\circ} \mathrm{C}$ lower than corresponding APS oligomers ${ }^{4}$. These two experimental studies provided evidence that DNA containing "A-T" base pairs can form both PS-DNA and APS-DNA. In 1992, Tchurikov et al. showed that parallel complementary probes of normal nucleotide consisting of both AT/GC base pairs can be used for molecular hybridization experiments, indicating the stability of G-C containing parallel DNA ${ }^{5}$. In 1993, Borisova et al. reported that G-C pairs in a 40 base pair parallel duplex DNA (consisting of natural DNA sequence) are more thermostable than A-T base pairs ${ }^{6}$. Furthermore, other similar reports have shown that there are no drastic differences in nearest neighbor base pair interactions between PS-DNA and APS-DNA having mixed AT/GC composition ${ }^{7}$. The specificity of the interaction between the strands in parallel DNA has also been studied and it is so high that parallel probe as short as 40 nucleotide length is able to detect a specific band in Southern blot hybridizations on whole genome DNA ${ }^{8}$. The polymerase chain reaction (PCR) developed by Mullis consists of denaturation of double-stranded DNA, primer annealing and extension. The process is repeated multiple times and the template DNA is amplified millions of times without any change in polarity of DNA 9 (Figure 1). In 2000, Veitia and Ottolenghi reported that several attempts to amplify L15253 by PCR using different pairs of primers were unsuccessful. They suggested that there are no thermodynamic constraints which will prevent parallel nucleic acid synthesis, and the deoxynucleotide triphosphates used for a normal antiparallel polymerization reaction can also serve for a parallel reaction, provided that the polymerase enzyme is capable in catalyzing the nucleophilic interaction between the $3^{\prime} \mathrm{OH}$ and a $5^{\prime} \mathrm{PPP}$ from nucleotides arranged in a parallel way with respect to the template $\mathrm{DNA}^{10}$.

In this study, we explored whether parallel DNA synthesis is feasible. We proposed the hypothesis that this reaction can be possible if we start a reaction using single stranded DNA as a template. We have shown that the Taq DNA polymerase can even extend the oligonucleotide primer annealed to single stranded DNA in a parallel complementary manner. The details of how our proposed parallel DNA PCR differs from the conventional PCR is shown in Figure 1 and Figure 2.

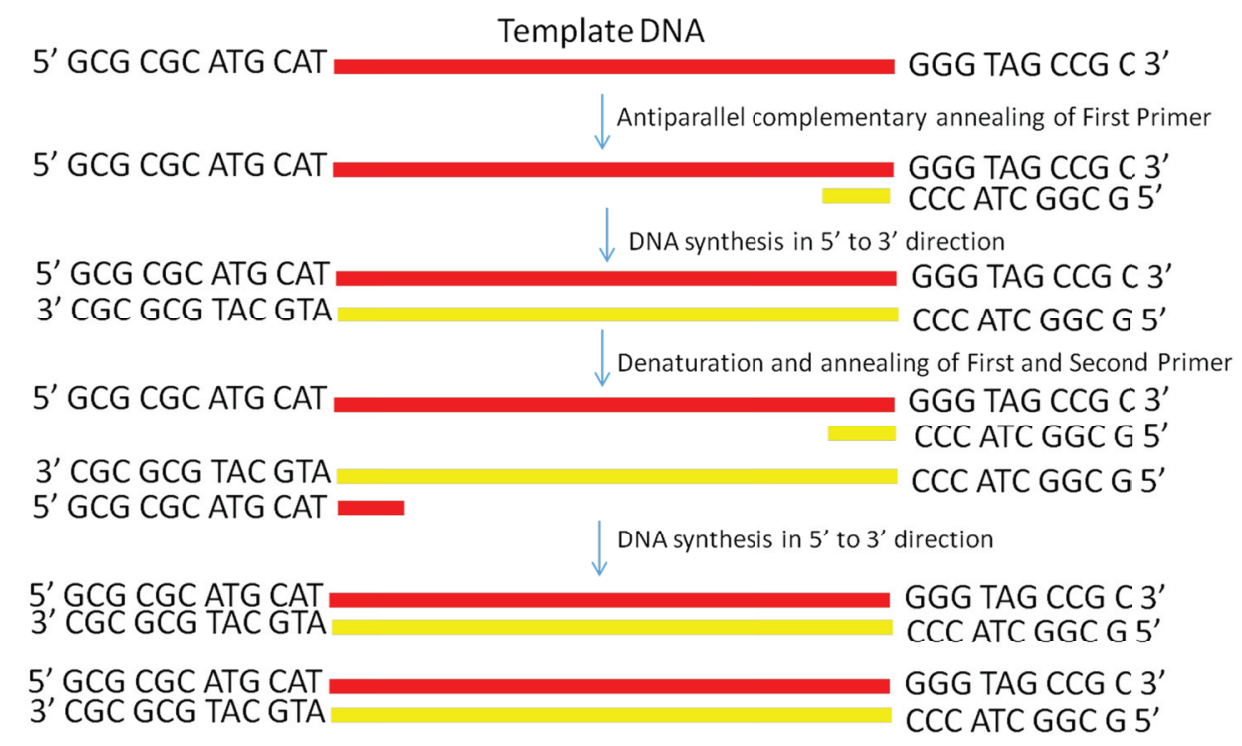

Figure 1. Schematic diagram showing PCR amplification of a single-stranded DNA by using conventional antiparallel oligonucleotide primers. 


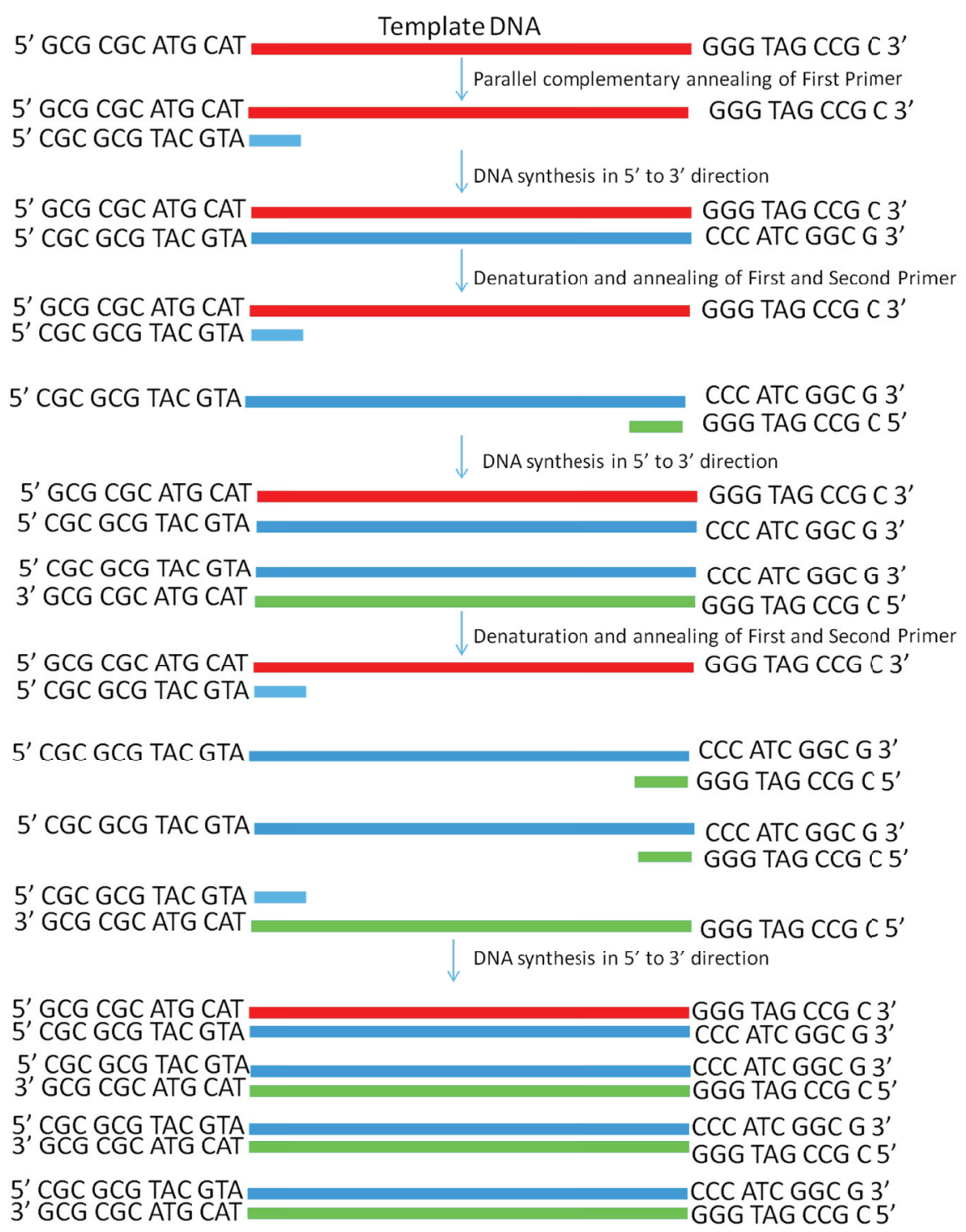

Figure 2. Schematic diagram showing PCR amplification of a single-stranded DNA by using the PD-PCR (parallel DNA PCR) approach in which the first primer binds to the template DNA in a parallel complementary manner. The second primer binds to the newly synthesized DNA in an antiparallel manner and later both primers amplify the new DNA in a conventional manner. PCR products obtained will have opposite polarity as compared to the template used.

\section{Materials and methods \\ PCR}

PAGE purified single stranded DNA of 120 bp was commercially obtained at a scale of 1 O.D. from Sigma Aldrich, USA. PCR oligonucleotide primers were also purchased at a scale of 0.05 O.D. from Sigma Aldrich. The sequence of custom synthesized template DNA and oligonucleotide primers used in the study are shown in Table 1. In the PD-PCR reaction, we used (PD-PCR-1) and (PD-PCR-2) primer set while for conventional PCR we used (PCR-1) and (PCR-2) primers (see Table 1). Rest of the reaction remained same. The details of PCR reaction mix were as follows: total reaction mix $=50 \mu \mathrm{l}$, primers $=1 \mu \mathrm{l}$ each (50 picomole), Taq DNA polymerase $=0.5 \mu \mathrm{l}(5 \mathrm{U} / \mu \mathrm{l}), \mathrm{dNTP} \operatorname{mix}=0.5 \mu \mathrm{l}(10 \mathrm{mM}), 10 \mathrm{X}$ PCR buffer $=5 \mu \mathrm{l}$, water $=39 \mu \mathrm{l}$ and template DNA $=3 \mu \mathrm{l}(0.114 \mathrm{ng})$.
Taq DNA polymerase (M0273S) and dNTP mix (N0447S) were purchased from NEB (New England Biolabs). PCR analysis was performed using Veriti ${ }^{\circledR}$ Thermal Cycler (Applied Biosystem) by taking single stranded template DNA and amplifying it for 30 cycles at varying annealing temperature viz. $45^{\circ} \mathrm{C}, 50^{\circ} \mathrm{C}, 55^{\circ} \mathrm{C}, 58^{\circ} \mathrm{C}$, $60^{\circ} \mathrm{C}, 65^{\circ} \mathrm{C}$. PCR programming included 30 cycles of denaturation at $95^{\circ} \mathrm{C}$ for 15 seconds, annealing at varying temperatures for 30 seconds (as explained above) and extension at $72^{\circ} \mathrm{C}$ for 30 seconds.

Agarose gel electrophoresis

PCR products obtained in two reactions were separated on $1 \%$ agarose gel containing ethidium bromide and were run and observed in gel-doc (DNR Bioimaging system, Jerusalem, Israel) under UV. Electrophoresis apparatus used in these experiments was purchased from 


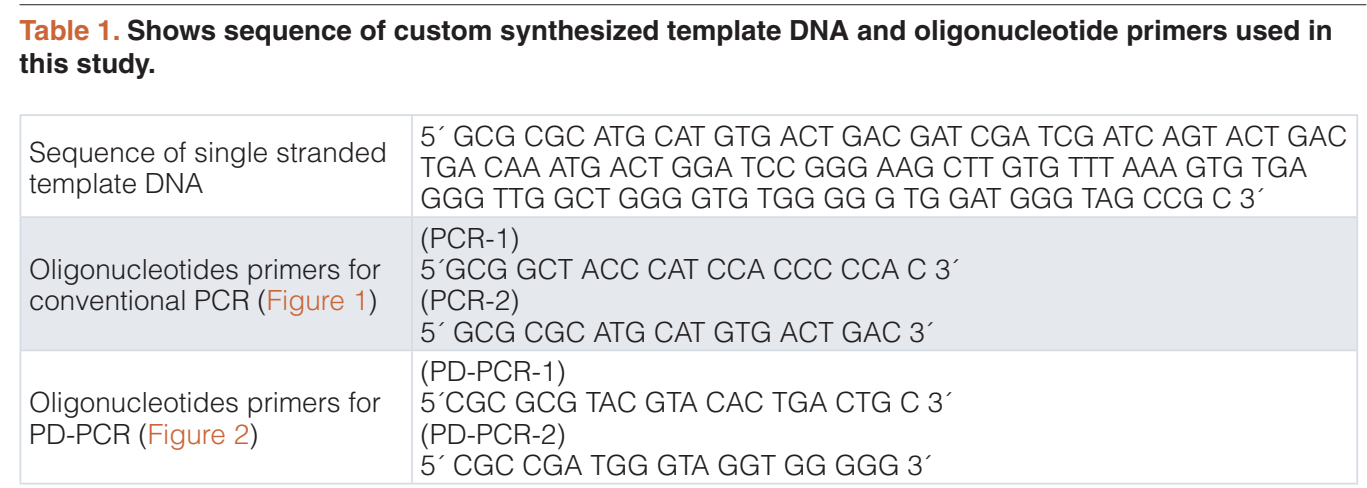

Chromus Biotech, Bengaluru, India whereas chemicals \{Agarose (A9539) and $\operatorname{EtBr}(E 7637)\}$ were purchased from Sigma, USA.

\section{Sequencing}

The amplified products were sequenced at Eurofins Genomics India Pvt. Ltd. Karnataka India.

\section{Real time PCR}

Real time PCR was performed with 2X SYBR Green master mix (K0221, Thermo Scientific, Pittsburgh, USA). The details of real time PCR reaction mix were as follows: total reaction $\operatorname{mix}=10 \mu \mathrm{l}$, primers $=0.25 \mu \mathrm{l}$ each, $(50$ picomole $), 2 \mathrm{X}$ SYBR green mastermix $=5 \mu \mathrm{l}$, water $=4 \mu \mathrm{l}$ and template $=0.5 \mu \mathrm{l}(1: 1000$ dilution from original stock of 0.96 picomole). In the PD-PCR reaction, we used (PD-PCR-1) and (PD-PCR-2) primer set while for conventional PCR we used (PCR-1) and (PCR-2) primers (see Table 1). Negative control included reaction mix without template DNA. Reactions were incubated at $94^{\circ} \mathrm{C}$ for 5 minutes, followed by 30 PCR cycles of $94^{\circ} \mathrm{C}$ for 15 seconds, $50^{\circ} \mathrm{C}$ for 30 seconds and $72^{\circ} \mathrm{C}$ for 60 seconds using Mx3005P qPCR System - Agilent Technologies, Inc. The data were analyzed by using $2^{-\Delta \mathrm{Ct}}$ method. The products were also run on agarose gel and visualised on gel doc system as previously described.

\section{Result and discussion}

Dataset 1. DNA sequencing file for PCR and PD-PCR

http://dx.doi.org/10.5256/f1000research.5813.d41515

DNA sequencing file (DNA sequencing file for PCR.ab1) confirming single stranded template DNA was amplified as it is while DNA sequencing file (DNA sequencing file for PD-PCR.ab1) confirming that single stranded template DNA was amplified as per our proposed PD-PCR scheme within this manuscript.
Dataset 2. Real time PCR file for PCR and PD-PCR

http://dx.doi.org/10.5256/f1000research.5813.d41516

Real time PCR amplification of single stranded DNA as per conventional PCR and PD-PCR.1 Data file

The thermal denaturation analysis of parallel DNA has shown that it melts at a lower temperature than the corresponding antiparallel structure $^{3,4}$. This finding gives us the clue that using double-stranded antiparallel DNA as a template for PD-PCR will not be possible as during annealing steps, antiparallel double-stranded DNA will anneal to itself without binding to parallel-stranded complementary primers. To avoid this, we started our PCR with a single-stranded DNA template. Details on how our proposed parallel DNA PCR (PD-PCR) differs from conventional PCR are shown in Figure 2. The first oligonucleotide primer (PD-PCR-1) was designed to bind the single-stranded template DNA in a parallel complementary manner. The parallel complementary annealing of the first primer allowed the synthesis of DNA in a parallel direction to the singlestranded DNA template. After the first denaturation step, the second oligonucleotide primer (PD-PCR-2) was designed to anneal to the newly synthesized DNA in an antiparallel complementary orientation. Further, both first and second primers used in this reaction amplified the new second DNA strand in a conventional way by binding in an antiparallel complementary way. Figure 3 (lanes 8-13) shows a $120 \mathrm{bp}$ PCR product amplified by parallel DNA PCR scheme at annealing temperature of $45^{\circ} \mathrm{C}, 50^{\circ} \mathrm{C}, 55^{\circ} \mathrm{C}, 58^{\circ} \mathrm{C}, 60^{\circ} \mathrm{C}$, $65^{\circ} \mathrm{C}$ respectively. In all cases, denaturation was performed at $95^{\circ} \mathrm{C}$ for 15 seconds, annealing for 30 seconds while extension at $72^{\circ} \mathrm{C}$ for 30 second for a total of 30 cycles. Similarly, as a control reaction, the single-stranded 120 bp DNA was amplified by conventional PCR in which the first primer (PCR-1) bound to the template

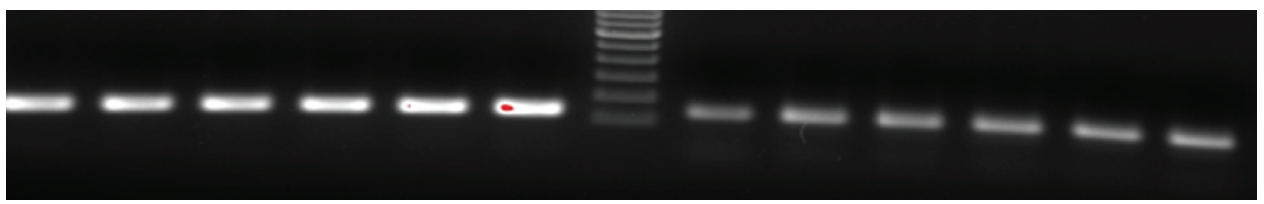

Figure 3. PD-PCR (parallel DNA PCR) and PCR: Lanes 1-6 show 120 bp PCR products amplified at annealing temperature of $45^{\circ} \mathrm{C}$, $50^{\circ} \mathbf{C}, 5^{\circ} \mathbf{C}, 5^{\circ} \mathbf{C}, \mathbf{6 0}^{\circ} \mathbf{C}, \mathbf{6 5}^{\circ} \mathbf{C}$, respectively, using conventional antiparallel complementary primers. Lane 7 is 100 bp molecular weight marker and Lanes 8-13 show PCR products amplified by parallel DNA PCR scheme at annealing temperature of $45^{\circ} \mathrm{C}, 50^{\circ} \mathrm{C}, 55^{\circ} \mathrm{C}, 58^{\circ} \mathrm{C}$, $60^{\circ} \mathrm{C}, 65^{\circ} \mathrm{C}$, respectively. In all cases, denaturation was performed at $95^{\circ} \mathrm{C}$ for 15 seconds, annealing for 30 seconds while extension at $72^{\circ} \mathrm{C}$ for 30 second for a total of 30 cycles. 
DNA in an antiparallel orientation and the second primer (PCR-2) annealed to the newly synthesized DNA in an antiparallel orientation. Figure 3, Lanes 1-6 shows a 120 bp product PCR amplified at annealing temperature of $45^{\circ} \mathrm{C}, 50^{\circ} \mathrm{C}, 55^{\circ} \mathrm{C}, 58^{\circ} \mathrm{C}, 60^{\circ} \mathrm{C}$, $65^{\circ} \mathrm{C}$ respectively using conventional antiparallel complementary primers. As a control reaction, PD-PCR was also performed using only one of the two primers. As expected, no PCR products were obtained (Figure 4A lane 2 and 3). As a control reaction, conventional PCR and PD-PCR were performed without adding any template DNA. As expected, no PCR product was obtained confirming that no primer dimer was formed during both conventional PCR and PD-PCR (Figure 4B). The DNA sequencing results confirmed that DNA templates were amplified in two different PCR products. Conventional PCR amplified the template DNA in its original orientation (Figure 5A) whereas PD-PCR products read in a parallel direction to the template DNA (Figure 5B). Primers and template used to show feasibility of PD-PCR till now (Figure 3 and Table 1) were further used to perform real-time PCR. For this, a master mix containing SYBR Green and other components (except template and primers) was used. Primers and template were added to the master mix to make a final volume of $10 \mu \mathrm{l}$. A Ct value of 9.26 was obtained for conventional PCR, 23.29 for PD-PCR whereas 33.15 was observed in negative control (without adding template DNA) indicating amplification in both conventional PCR and PD-PCR reactions (Figure 6). The amplification indicated by $\mathrm{Ct}$ value in real time PCR was also confirmed by running the product on agarose gel (Figure 6, lower panel). Weak amplifications in PD-PCR may be attributed to the fact that the actual amplification in conventional PCR is one step ahead than the PD-PCR. The first amplification in conventional PCR starts as early as denaturation followed by annealing (Figure 1). On the other hand, in PD-PCR a new template is first synthesized during the first amplification (represented by green color in Figure 2). Once the template is ready, the conventional PCR goes on. Therefore, the amplified product shows low intensity as compared to the conventional PCR products. Taking together, our study has shown that DNA synthesis can happen in a parallel direction and two different, but related PCR products can be synthesized from the single-stranded template DNA. We hope that more molecular biology techniques will develop in future based on parallel complementary bindings of duplex DNA.

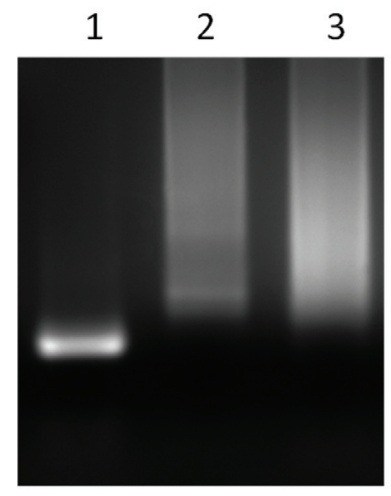

(A)

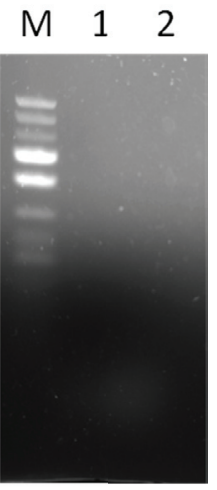

(B)
Figure 4. (A): A control reaction showing that PCR products were obtained when both primers were added as per scheme in Figure 2. In Figure 4 (A), Lane 1 shows 120 bp PCR products synthesized by PD-PCR, while in Lanes 2 and 3, only single primers were added and as expected no PCR product was synthesized. Figure 4(B) shows a negative control reaction of conventional PCR and PD-PCR in which the template DNA was not added.

Fig (A)

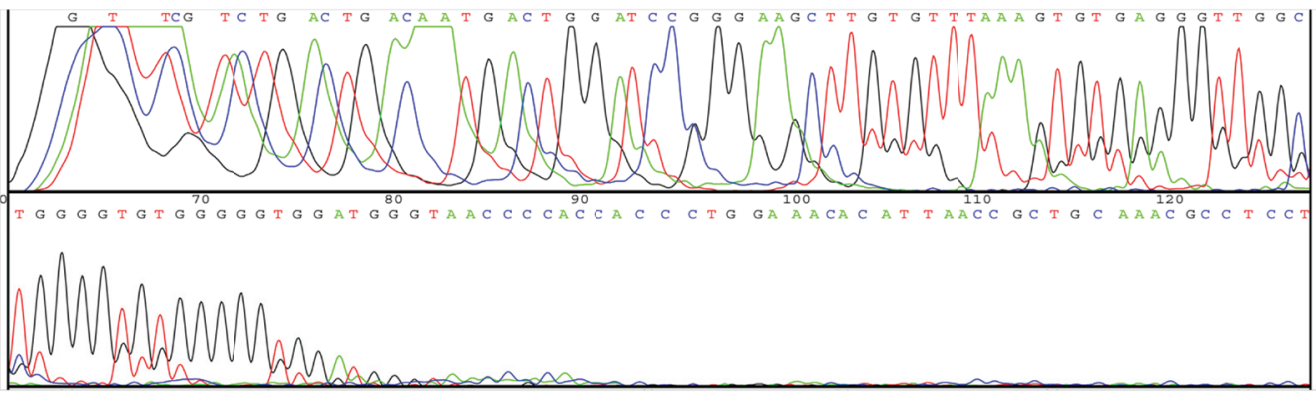

Fig (B)

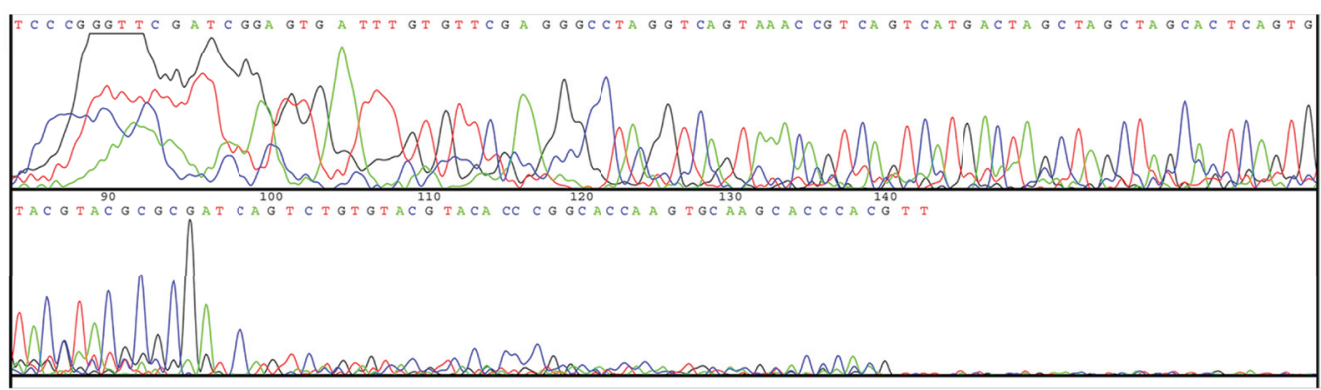

Figure 5. DNA sequencing results. Sequencing results in (A) show that $120 \mathrm{bp}$ DNA was amplified as it is while sequencing results in (B) confirm that PCR products were obtained as per the scheme shown in Figure 2. 

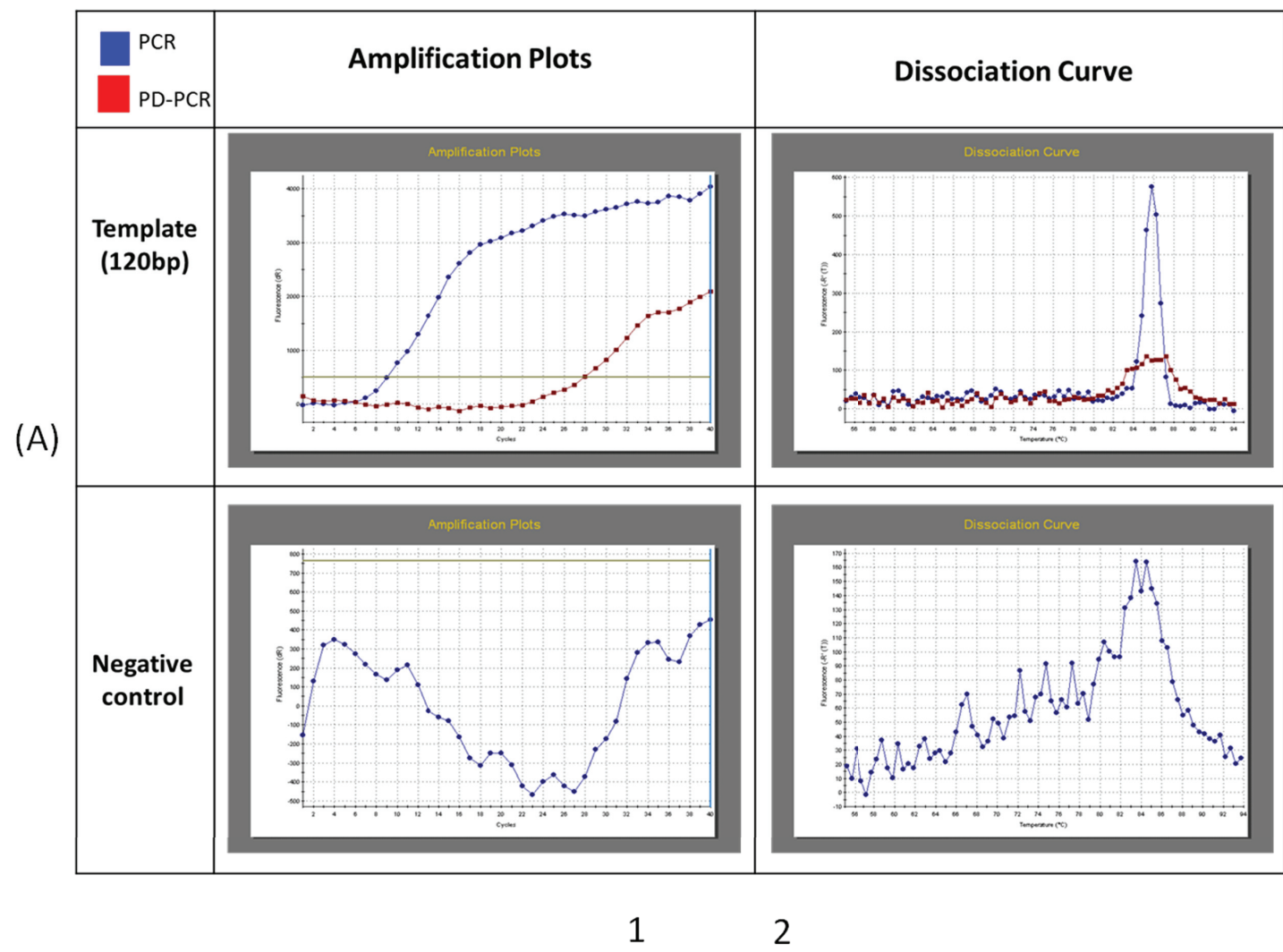

(B)

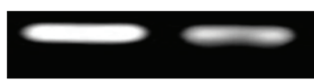

Figure 6. Real time PCR and PD-PCR (A) show ampliflication plot and dissociation curves obtained after real time PCR analysis of amplification of 120 nucleotides single stranded template DNA via conventional PCR and PD-PCR. In control reaction no template DNA was added. (B) PCR products obtained in real time PCR were also run on agarose gel and visualised on gel doc system.

\section{Data availability}

F1000Research: Dataset 1. DNA sequencing file for PCR and PDPCR. 10.5256/f1000research.5813.d41515 11

F1000Research: Dataset 2. Real time PCR file for PCR and PDPCR. 10.5256/f1000research.5813.d41516

\section{Author contributions}

$\mathrm{VB}$ and KS designed the experiment. VB and KS carried out the research. Both prepared the manuscript.

\section{Competing interests}

No competing interests were disclosed.

Grant information

The author(s) declared that no grants were involved in supporting this work.

Acknowledgments

We are thankful to Harpreet Singh (Territory Manager, SigmaAldrich, Gujarat, India) for providing the custom synthesized template DNA and oligonucleotide primers used in this study.

\section{References}

1. Watson JD, Crick FH: Molecular structure of nucleic acids; a structure for Deoxyribose Nucleic Acid. Nature. 1953; 171(4356): 737-738. PubMed Abstract I Publisher Full Text

2. Pattabiraman N: Can the Double Helix Be Parallel? Biopolymers. 1986; 25(9): 1603-1606.

PubMed Abstract I Publisher Full Text

3. Ramsing NB, Jovin TM: Parallel stranded duplex DNA. Nucleic Acids Res. 1988; 16(14A): 6659-76.

PubMed Abstract I Publisher Full Text | Free Full Text

4. van de Sande JH, Ramsing NB, Germann MW, et al:: Parallel Stranded DNA.
Science. 1988; 241(4865): 551-557.

PubMed Abstract I Publisher Full Text

5. Tchurikov NA, Shchyolkina AK, Borissova OF, et al:: Southern molecular hybridization experiments with parallel complementary DNA probes. FEBS Lett. 1992; 297(3): 233-236.

PubMed Abstract I Publisher Full Text

6. Borisova OF, Shchyolkina AK, Chernov BK, et al:: Relative stability of AT and GC pairs in parallel DNA duplex formed by a natural sequence. FEBS Lett. 1993; 322(3): 304-6. PubMed Abstract I Publisher Full Text

7. Shchyolkina AK, Borisova OF, Livshits MA, et al.: [Parallel-stranded DNA with 
natural base sequences]. Mol Biol. 2003; 37(2): 223-231.

PubMed Abstract I Publisher Full Text

8. Tchurikov NA, Shchyolkina AK, Borissova OF, et al:: Southern molecular hybridization experiments with parallel complementary DNA probes. FEBS Lett. 1992; 10: 297(3): 233-6.

PubMed Abstract I Publisher Full Text

9. Mullis KB: Process for amplifying nucleic acid sequences, United States Patent 4683202. 1987.

Reference Source
10. Veitia R, Ottolenghi C: Placing parallel stranded DNA in an evolutionary context. J Theor Biol. 2000; 206(2): 317-322. PubMed Abstract I Publisher Full Tex

11. Bhardwaj V, Sharma K: Dataset 1. DNA sequencing file for PCR and PD-PCR. F1000Research. 2014.

Data Source

12. Bhardwaj V, Sharma K: Dataset 2. Real time PCR file for PCR and PD-PCR. F1000Research. 2014.

Data Source 


\section{Open Peer Review}

\section{Current Peer Review Status:}

\section{Version 1}

Reviewer Report 19 January 2015

https://doi.org/10.5256/f1000research.6214.r7174

(C) 2015 Gopal R. This is an open access peer review report distributed under the terms of the Creative Commons Attribution License, which permits unrestricted use, distribution, and reproduction in any medium, provided the original work is properly cited.

\section{Ram Gopal}

Department of Cell and Molecular Biology, Uppsala University, Uppsala, Sweden

It is interesting to read the article 'Parallel DNA polymerse chain reaction: Synthesis of two different PCR products from a DNA template' by Bhardwaj and Sharma. The authors for the first time have demonstrated that primers can anneal in parallel orientation and can be extended in a $\mathrm{PCR}$ reaction. They have used state of the art technique real time PCR to demonstrate this along with the conventional agarose gel electrophoresis and DNA sequencing reaction. Definitely, this opens up many possibilities in the field of molecular biology. The research is well designed and presented in a clear and comprehensible way. The introduction section gives a very nice insight. However, I suggest following minor changes to improve the manuscript.

1. Figure 3- Numbering should be done on the loading wells.

2. Figure 5- Sequencing results should be presented in such a way that one can easily compare the APS and PS sequences easily. For example they can put a arrow mark from where to compare.

3. Figure 6- It is difficult to read the abscissa and ordinate scale and naming. Increasing the font will help.

4. Line 11- $d(A) 6 d .(T) 6$ should be explained or is it $d A_{6} d T_{6}$ ?

5. In the RT PCR section the term Ct value should be explained so that a non-expert reader can benefit.

6. There are some typos errors scattered in the manuscript. Such as $50 \mu$ l should be $50 \mu \mathrm{L}$.

Competing Interests: No competing interests were disclosed.

I confirm that I have read this submission and believe that I have an appropriate level of 
expertise to confirm that it is of an acceptable scientific standard.

Reviewer Report 12 January 2015

https://doi.org/10.5256/f1000research.6214.r7172

(c) 2015 Madhyastha $\mathbf{H}$. This is an open access peer review report distributed under the terms of the Creative Commons Attribution License, which permits unrestricted use, distribution, and reproduction in any medium, provided the original work is properly cited.

\section{Harishkumar Madhyastha}

Department of Applied Physiology, Faculty of Medicine, Miyazaki Medical College, Miyazaki, Japan

The title of the research paper is well justified and suitable to the content of the subject. Abstract of the paper is well written and concluded. Materials and method, data analysis and design of the experiment are commendable. In my opinion, the paper is well written and opens a new paradigm for researchers and finally, the conclusion arrived at shows the high standard of the scientific achievement. In all respects, the paper is highly novel and can be indexed.

Competing Interests: No competing interests were disclosed.

I confirm that I have read this submission and believe that I have an appropriate level of expertise to confirm that it is of an acceptable scientific standard.

\section{Comments on this article}

\section{Version 1}

\section{Reader Comment 21 Jul 2015}

Nickolai Tchurikov, Engelhardt Institute of Molecular Biology, Russian Federation

Dr. Vikash Bhardwaj,

I made some experiments on to test a possibility of parallel synthesis in March, 2015. I used the template corresponding to that described in your paper, but shorter:

\section{5'GCGCGCATGCATGTGACTGACGATCGATCGATCAGTACTGACTGACAAATGAGT} GGGGGTGGATGGGTAGCCGC3'(template, Olig №1).

In bold the region located between the primers and designated for testing of parallel synthesis is shown.

Expected par-template (see below)could appear after extension of a primer $[p a r(+)$ 
5'CGCGCGTACGTACACTGACTGC 3'] that is complementary in parallel orientation to the template. It was performed using a mixture of several DNA polymerases including three thermostable ones - at $37^{\circ} \mathrm{C}$ and then at $72^{\circ} \mathrm{C}$.

The sequence of expected DNA is:

\section{5'CGCGCGTACGTACACTGACTGCTAGCTAGCTAGTCATGACTGACTGTTTACTCA CCCCCACCTACCCATCGGCG3' (par-template).}

For amplifications of putative par-template I used the mixture after this primer extension, containing the chemically synthesized template (in great molar excess!!!) and, as I suggest cannot be excluded, traces of putative par-template, that may correspond to not complete sequence of the shown par-template.

For regular PCR amplification of par-template two primers were used - №4$\operatorname{par(+)5'CGCGCGTACGTACACTGACTGC~3'and~№5-~par(-)~5'~CGCCGATGGGTAGGTGGGGG~3',~that~are~}$ complementary to par-template in antiparallel orientation.

The same mixture were used for amplification of template (№1) and primers №2 ap(+) 5'GCGCGCATGCATGTGACTGACG 3' and №3 ap(-) 5'GCGGCTACCCATCCACCCCCAC 3'.

The results are shown in the linked file. ap - PCR with primers №1 and 2; p - PCR with primers №4 and №5.

The amplified DNAs were cloned and sequenced. All ap-clones corresponded to the oligos №1, as expected.

About 50 par-clones were sequenced. Mostly they correspond to the text of original template shown in bold (in oligos №1) located between par-primers, indicating that primers №4 and №5 are capable to anneal to the original template that is present in a great excess.

Two par-clones (\#11 and 42) were different and possibly possess some short sequences that could be explained either by extension of primer № 4 in parallel orientation, or by combination of sequences of original olig №1 and primer №5. I have no time for a careful analysis. E.g. GCGGCTACCCATCCACCCCCACCTACCCATCGGCG 3'- mirror hairpin with a loop in \#42.

I am sorry that this nice gel gave such clones.

New experiments with well thought template sequences (may be with low GC-content) could be used. Only sequence of individual clones should be performed. The careful analysis of unusual short stretches of mirror sequences should be performed. I suggest to reduce dramatically the content of original template using 5'-biotinylated templates that could be separated from partemplate using PMP-particles.

Sincerely, Nickolai. 
P.S. I should say that the mirror sequences in these experiments may also mean simply annealing of (-) primer designed for regular amplification of par-template in the 3' region of original template which possess mirror stretch of the same nucleotides.

Competing Interests: No competing interests were disclosed.

\section{Author Response 02 Mar 2015}

Dr Vikash Bhardwaj, Lovely Professional University, Punjab , India, India

\section{Dear Reiner Veitia}

We have attached two separate communications we received earlier from you.

The first one says "I have read your preprint on parallel DNA with lot of interest. It was like 15 years flash back when I was making the same experiments at the Pasteur Institute in Paris. However, I recall having lots of problems, not with the synthesis but with contaminations. The long oligos were contaminated with traces of my normal long control. So that in the end, I had amplified in the normal way that is probably favoured".

The second one says "What I propose you to do is to device a strategy that avoids any potential contamination as I had many years ago. For instance, I order a long 100 bases oligo and a small one to replicate in a "parallel" fashion and then others to amplify normally the newly synthesized strand by std PCR (but not recognizing the original strand".

We would like to highlight that strategy proposed by you is vulnerable for contamination. The reasons are as follows a) The first primer "the small one" to replicate in parallel fashion will also amplify the newly synthesized DNA in an antiparallel way in later reactions (checkout our PD-PCR strategy). B) One of the two primers used to detect newly synthesized DNA by standard PCR will start initiating a new shorter parallel DNA synthesis reaction and it might have also interfere in parallel DNA synthesis by first primer "the small one". As you have used three primers in a single reaction it might have given you contamination along with traces of normal long control. This is the reason we followed our strategy only (as explained in the article).

Regarding your recent comments on our manuscript saying that you were not able to amplify template DNA as per our approach using Herculase II enzyme, we would like to specify that we have used Taq DNA polymerase enzyme which do not have proof reading activity and you have used an enzyme which have high proof reading activity. From this information, we conclude that the enzyme which has proof-reading activity (evolutionary advanced) might have lost the capabilities to synthesize in parallel direction with respect to their evolution. We would also like to validate this from our end.

We also suggest readers to increase the number of cycles (50-60 cycles) in case they are getting weaker amplification. As with increasing number of PCR cycles, half life of the enzyme will reduce, You may also add extra unit of enzymes after 30 cycles. We wish to say readers that we have tested two more templates DNA by PD-PCR and we have got expected amplification through the proposed 
strategy. If interested, we may also send our DNA samples and oligos to any reader/s to validate the findings at their lab.

Dr Vikash Bhardwaj

Dr Kulbhushan Sharma

Competing Interests: No competing interests were disclosed.

Reader Comment 17 Feb 2015

Reiner Veitia, France

I have now had the opportunity to repeat this experiment with the same template and parallel primers as described in the MS and unfortunately failed to obtain any amplification (at 45C and 55C). The only variation to the protocol was the use of the polymerase Herculase II. This reminds me of my failure over 15 years ago when I tried the same (with many different polymerases in an array of different conditions, T, Mg2++, etc). Although this synthesis can be possible in thermodynamic terms, I don't know if current polymerases can perform it in "so standard" conditions as described in the paper.

When I discovered the preprint citing my previous theoretical/bioinformatical work I engaged in a conversation with Vikash Bhardwaj who said that "all these experiment which are simple to reproduced. Anybody having molecular biology lab can do that.....and if any body feels it is very simple, let them say they did the experiment and did not get results".

I invite the readers to try to replicate this result, which would be very interesting if confirmed. In my trials, past and present, perhaps I simply failed to find the right conditions (in which case, they are not that simple to find). I can also propose you (the readers) a blind experiment in which I send template and primers to you and you give me back the sequence (in the same way I proposed to Vikash during our conversation).

My email: alveitfr@yahoo.fr.

Competing Interests: No competing interests

Author Response 07 Feb 2015

Dr Vikash Bhardwaj, Lovely Professional University, Punjab , India, India

Check out the following report published at Genomeweb site by Madeleine Johnson

"Study Claims PCR from Primers Annealed in Parallel Orientation"

Competing Interests: No competing interests were disclosed. 
The benefits of publishing with F1000Research:

- Your article is published within days, with no editorial bias

- You can publish traditional articles, null/negative results, case reports, data notes and more

- The peer review process is transparent and collaborative

- Your article is indexed in PubMed after passing peer review

- Dedicated customer support at every stage

For pre-submission enquiries, contact research@f1000.com 